\title{
Purification of Pili from Bacteroides nodosus and an Examination of their Chemical, Physical and Serological Properties
}

\author{
By D. EVERY \\ Wallaceville Animal Research Centre, Research Division, \\ Ministry of Agriculture and Fisheries, Private Bag, Upper Hutt, New Zealand
}

(Received 15 March 1979; revised 18 May 1979)

\begin{abstract}
Pili from Bacteroides nodosus were purified to greater than $99 \%$ homogeneity by precipitation at $\mathrm{pH} \mathrm{4.0}$ and in $\mathrm{MgCl}_{2}$ followed by chromatography on BioGel A150. The pili were composed entirely of one type of polypeptide subunit, pilin. No carbohydrates, nucleic acid, lipid, lipopolysaccharide or phosphate could be detected in purified pili preparations. The molecular weight of pilin from B. nodosus strains $91 \mathrm{~B}$ and 198 was 18400 and from strain 80 was 19300 . The isoelectric points of pili from $B$. nodosus strains $91 \mathrm{~B}$ and 80 were both 4.5 . The buoyant densities of pili from strains $91 \mathrm{~B}, 80$ and 198 were $1.287,1.284$ and 1.286 $\mathrm{g} \mathrm{ml}^{-1}$, respectively. The three strains of $B$. nodosus did not cross-react in $\mathrm{K}$-agglutination tests and produced pili which did not cross-react in immunodiffusion tests. Antiserum to highly purified pili caused a characteristic K-type agglutination reaction. It was concluded that pili are the K-agglutinogen.
\end{abstract}

\section{INTRODUCTION}

Large numbers of pili have been observed on the surface of Bacteroides nodosus on primary isolation from sheep affected with foot rot (Short et al., 1976; Cooper, 1977). In serial subcultures of these isolates, however, bacteria bearing only low numbers of pili may appear and it has been shown that these organisms, when compared with highly piliated $B$. nodosus, form colonies of different morphology (Stewart, 1975a, b; Short et al., 1976; Thorley, 1976), have low virulence for sheep and do not protect inoculated animals from foot rot infection (Stewart, 1975a, b).

Stewart (1973) and Walker et al. (1973) reported that sera from sheep inoculated with partially purified preparations of $B$. nodosus pili gave the typical K-type agglutination with whole bacteria as described by Egerton (1973); moreover, such sheep were resistant to experimental foot rot challenge (Stewart, 1975a, $b, 1978 a$ ). Using immuno-electron microscopy, Walker et al. (1973) demonstrated that K-type agglutination may be caused by antibodies binding pili together and suggested that in vaccinated animals, anti-pili antibodies penetrating to the site of the hoof lesion might immobilize B. nodosus organisms and so prevent spread of the epidermal infection.

For further investigations of the relationships between pili, the K-agglutinogen and the antigens associated with immunity, preparations free from any other cellular components were desirable. This paper describes the purification of B. nodosus pili to greater than $99 \%$ homogeneity and reports their chemical, physical and serological properties.

\section{METHODS}

Bacterial strains and growth conditions. The Bacteroides nodosus strains studied included two New Zealand isolates (strains 91B and 80) and one from Australia (strain 198). The organisms were grown anaerobically in TAS liquid medium as described by Skerman (1975). The number of subcultures was kept to a minimum to preclude selection of variant organisms which produce low yields of pili (Stewart, 1973; Short et al., 1976). 
Electron microscopy. Bacteria or isolated pili were suspended in drops of saline $(0 \cdot 15 \mathrm{M}-\mathrm{NaCl})$ on Parafilm (American Can Company, Dixie/Marathon, Greenwich, U.S.A.) upon which collodion-coated grids were floated for $1 \mathrm{~min}$; the grids were then transferred to drops of $0.5 \%$ (w/v) uranyl acetate in water at $\mathrm{pH} 4.5$ for $4 \mathrm{~min}$. Grids dried with blotting paper were examined in a Philips EM 201C transmission electron microscope and isolated pili were graded quantitatively as follows: $(+)$, pili just detectable on the grid; + , low numbers of widely separated pili; $2+$, many pili, only just separated; $3+$, light mat of pili; $4+$, dense mat of pili, obscuring almost all the grid.

Isolation and partial purification of pili. Bacteria from cultures in the late-exponential phase of growth were harvested in a continuous flow centrifuge. More pili were free in the growth medium than were attached to bacteria.

To remove attached pili, bacteria in the sediment were resuspended in ice-cold 0.01 M-phosphate buffer, pH 7.2, containing $0.147 \mathrm{M}-\mathrm{NaCl}$ (phosphate-buffered saline) and homogenized at full speed in a Sorval Omnimix for $30 \mathrm{~s}$ while in an ice bath. Homogenization was repeated four times with cooling intervals between. The depiliated organisms and debris were removed by three centrifugations at $12000 \mathrm{~g}$ for $10 \mathrm{~min}$.

Unattached pili were removed from the culture supernatant by overnight precipitation at $\mathrm{pH} 4 \cdot 0$ followed by continuous flow centrifugation at $12000 \mathrm{~g}$.

The pili removed directly from bacteria (bacteria-derived pili) and those derived from the culture medium (medium-derived pili) were then separately purified by the same procedure. The initial purification steps were as described by Brinton (1965): three precipitations at $\mathrm{pH} 4 \cdot 0$ followed by repeated precipitations with $0 \cdot 1$ $\mathrm{M}-\mathrm{MgCl}_{2}$.

Gel filtration chromatography. The pellet from the final $\mathrm{MgCl}_{2}$ precipitation was dispersed in $5 \mathrm{ml} 25 \mathrm{~mm}-$ boric acid buffer, pH 8.5, containing 2 mM-EDTA, $0.5 \mathrm{M}-\mathrm{KCl}, 0.5 \%$ (w/v) non-ionic detergent Lubrol WX (Sigma) and $0.02 \%(\mathrm{w} / \mathrm{v}) \mathrm{NaN}_{3}$, and incubated at $37^{\circ} \mathrm{C}$ for $40 \mathrm{~min}$. The sample was run into the top of a $2.6 \times 100 \mathrm{~cm}$ column connected in series with a $2.6 \times 40 \mathrm{~cm}$ column both containing BioGel A150 (Bio-Rad Laboratories). The sample was eluted downwards at $14 \mathrm{ml} \mathrm{h}^{-1}$ with $25 \mathrm{~mm}$-boric acid buffer, $\mathrm{pH} 8 \cdot 5$, containing $2 \mathrm{~mm}$-EDTA, $0.5 \mathrm{M}-\mathrm{KCl}$ and $0.02 \%(\mathrm{w} / \mathrm{v}) \mathrm{NaN}_{3}$. The fractions $(7 \mathrm{ml})$ collected from the column were examined for pili in the electron microscope. The ultraviolet (u.v.) absorption spectra and lipopolysaccharide (LPS) content were also determined. Fractions containing pili free of LPS were pooled and concentrated by precipitation at $\mathrm{pH} \mathbf{4} \cdot \mathbf{0}$.

Isoelectric focusing. Isoelectric focusing of pili preparations was carried out in a LKB ampholine column (type 8101$)$ at $4{ }^{\circ} \mathrm{C}$. A sucrose gradient $(0$ to $50 \%$, w/v) containing $3 \%(\mathrm{w} / \mathrm{v})$ ampholine was prepared according to the manufacturer's instructions. The pili sample was dialysed against $1 \%(\mathrm{w} / \mathrm{v})$ glycine in distilled water and added to the mixing tube when about one-half of the gradient had been formed. A potential difference of 400 to $600 \mathrm{~V}$ was applied for 48 to $72 \mathrm{~h}$ until the current through the column reached a constant level of about $2.5 \mathrm{~mA}$ and the sample bands were stationary. Fractions $(2 \mathrm{ml})$ were collected, examined for pili and measurements were made of $\mathrm{pH}$ at $4{ }^{\circ} \mathrm{C}$ and absorbance at $280 \mathrm{~nm}$.

Iso-density gradient ultracentrifugation in caesium chloride. Pili ( 2 to $4 \mathrm{mg}$ ) were dispersed in $25 \mathrm{~mm}$-boric acid buffer, $\mathrm{pH} 8.5$, containing 2 mM-EDTA, $0.5 \mathrm{M}-\mathrm{KCl}, 0.02 \%(\mathrm{w} / \mathrm{v}) \mathrm{NaN}_{3}$ and $0.5 \%$ (w/v) Lubrol WX. $\mathrm{CsCl}$ was added to give a final concentration of $26 \%(\mathrm{w} / \mathrm{w})$ and the buoyant density of pili was determined by centrifugation in a $10 \times 10 \mathrm{ml}$ angle rotor in an MSE ultracentrifuge at $150000 \mathrm{~g}$ for $17 \mathrm{~h}$ at $20^{\circ} \mathrm{C}$. Fractions $(0.35 \mathrm{ml})$ were collected by puncturing the bottom of the centrifuge tube and the percentage transmission was measured at $280 \mathrm{~nm}$. The density was measured immediately at $20^{\circ} \mathrm{C}$ by weighing every second fraction and every fraction was examined for pili by electron microscopy.

Polyacrylamide gel electrophoresis. Sodium dodecyl sulphate (SDS)-polyacrylamide gel electrophoresis was carried out in glass tubes as described by Shapiro et al. (1967) with the following modifications recommended by Wyckoff et al. (1977); no SDS was included in the $3 \%(\mathrm{w} / \mathrm{v})$ polyacrylamide stacking gel or the $12 \%$ $(\mathrm{w} / \mathrm{v})$ separating gel, and only $0.03 \%(\mathrm{w} / \mathrm{v})$ SDS was incorporated in the running buffer. Standard proteins and pili samples were dissociated with SDS and dithiothreitol and prepared for electrophoresis as described by Wyckoff et al. (1977). After electrophoresis, the gels were stained for protein with Coomassie brilliant blue R250 (Wyckoff et al., 1977), for glycoprotein with periodic acid-Schiff's reagent (Segrest \& Jackson, 1972), for phosphoprotein using methyl green (Cutting \& Roth, 1973) and for lipid with oil red O (Abodeely et al., 1971). Densitometric scans of Coomassie blue-stained bands in the gels were carried out on a 'Quick Scan' densitometer (Helena Laboratories, Beaumont, Tex., U.S.A.) with a white light filter. The amount of protein in each band was estimated from the peak areas of the scans by comparison with ovalbumin and bovine serum albumin standards (up to $50 \mathrm{mg}$ per gel).

Molecular weights of the pilus subunits were calculated by the method of Shapiro et al. (1967) using the following standard proteins: lysozyme, human $\gamma$-globulin, ovalbumin (Sigma), soybean trypsin inhibitor and bovine serum albumin (Boehringer).

Antisera preparation. Anti-pili serum was prepared by inoculating adult sheep subcutaneously twice at a 
4 week interval with a total of $900 \mu \mathrm{g}$ of the most highly purified pili from strain $91 \mathrm{~B}$. The inoculum was prepared by emulsifying two parts of Freund's incomplete adjuvant (Arlacel/Drakeol; 1:9, v/v) with one part of pili dispersed in phosphate-buffered saline containing $0.5 \%(\mathrm{v} / \mathrm{v})$ neutral formalin. Antisera against intact bacteria of strains $91 \mathrm{~B}, 80$ and 198 were similarly raised in sheep inoculated with preparations containing a total of $10^{10}$ B. nodosus in Freund's incomplete adjuvant. Six weeks after the second injection blood was taken from the sheep and the sera were stored at $-20^{\circ} \mathrm{C}$.

Bacterial agglutination. Bacterial K-agglutination tests were carried out as described by Egerton (1974).

Immunodiffusion. The double-diffusion precipitin reaction was carried out as described by Ouchterlony (1958) using $0.9 \%$ Oxoid Ionagar no. 2 in phosphate-buffered saline containing $0.04 \%(\mathrm{w} / \mathrm{v}) \mathrm{NaN}_{3}$. The precipitin bands were stained with Coomassie brilliant blue R250 as described by Frost \& Paranchych (1977)

Chemical assays. Protein concentrations were determined by the Lowry method with bovine serum albu$\min$ as standard. Protein concentrations and nucleic acid contamination were also estimated by the u.v. absorption method of Warburg \& Christian (1941); this gave protein concentrations of pure pili preparations that were three-fifths of those obtained by the Lowry method. Carbohydrate was determined by the phenol/sulphuric acid reaction using glucose as standard (Dubois et al., 1956). LPS was estimated colorimetrically by the method of Janda \& Work (1971) using LPS purified from B. nodosus strain 80 by the method of Westphal \& Jann (1965) as a standard.

\section{RESULTS}

\section{Initial pili purification}

Except where stated otherwise, the results of purification methods refer to pili from $B$. nodosus strain $91 \mathrm{~B}$. The pili removed from bacteria by homogenization were morphologically identical to the free pili in the growth medium; both were 5 to $6 \mathrm{~nm}$ in diameter and up to $15 \mu \mathrm{m}$ long. After precipitation at $\mathrm{pH} 4.0$ and precipitation with $\mathrm{MgCl}_{2}$ five or six times, the pili preparations, whether bacteria-derived or medium-derived, were still contaminated with up to $20 \%$ nucleic acid, approximately $1 \%$ LPS and, as shown by SDS-polyacrylamide gel electrophoresis, by several proteins. In some preparations, the pili were free of nucleic acid after four or five $\mathrm{MgCl}_{2}$ precipitations, but were still contaminated with other proteins and LPS. The reason for these differences was not determined.

These impurities could not be removed by differential centrifugation at $20000 \mathrm{~g}$ for 20 $\min , 30000 \mathrm{~g}$ for $1.5 \mathrm{~h}$ and $105000 \mathrm{~g}$ for $2 \mathrm{~h}$. Anionic exchange chromatography on DEAEcellulose (Whatman DE 52) and fractional precipitation with $\left(\mathrm{NH}_{4}\right)_{2} \mathrm{SO}_{4}$ or methanol also failed to remove the impurities.

\section{Gel filtration chromatography}

Chromatography on BioGel A150 (Fig. 1) separated pili from LPS, nucleic acid and, as shown by SDS-polyacrylamide gel electrophoresis, virtually all the protein contaminants. The pili in the first absorption peak eluted from the BioGel column had a u.v. absorption spectrum typical of protein with an absorption maximum at approximately $278 \mathrm{~nm}$ and an inflection at $285 \mathrm{~nm}$. The nucleic acid was in the second peak which had an absorption maximum at $260 \mathrm{~nm}$. The yield of pili at this stage was about $5 \mathrm{mg}$ dry wt of protein per $10 \mathrm{~g}$ wet wt of bacteria.

Fractions from the first absorption peak eluted from the BioGel column were usually combined, concentrated and re-run on the same column to remove trace contaminants of LPS and nucleic acid. The final pili preparation had no detectable carbohydrates or LPS when enough pilin protein was used in the assay to detect a possible $0 \cdot 1 \%$ contamination. The u.v. absorption spectrum of purified pili indicated that all nucleic acid contaminants had been removed. Finally, the pili preparation appeared to be uncontaminated with other cell components when examined by electron microscopy. 


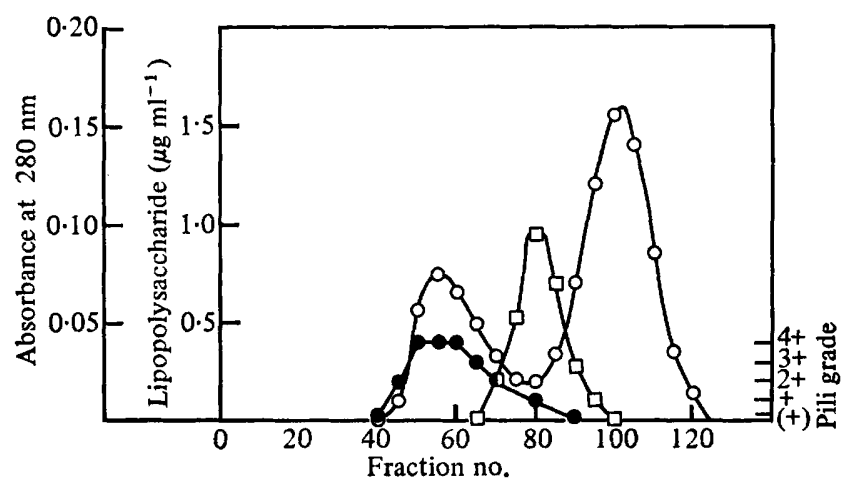

Fig. 1. Gel filtration of pili from strain 91B on BioGel A150. The pili sample applied to the column had previously been purified by acid precipitation and $\mathrm{MgCl}_{2}$ precipitation. The fraction volumes were $7 \mathrm{ml}$. $\bigcirc$, Absorbance at $280 \mathrm{~nm}$; $\square$, LPS; $\bullet$, pili grade.

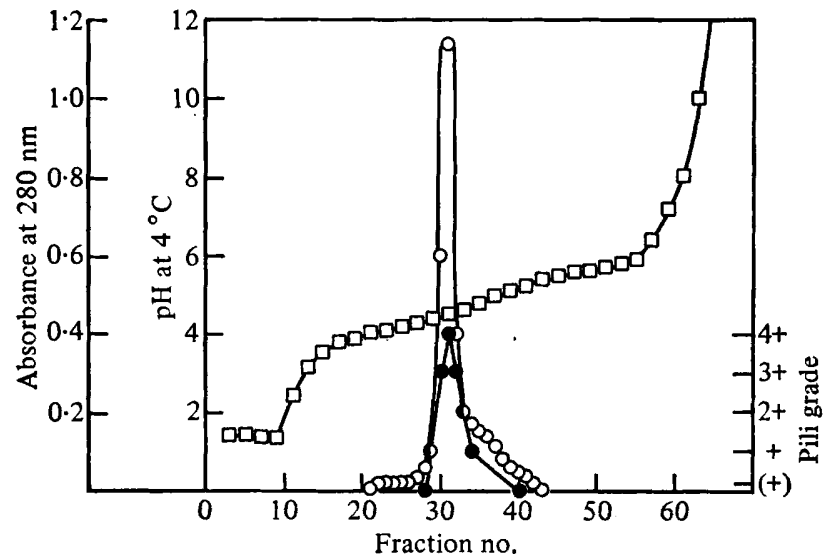

Fig. 2. Isoelectric focusing of pili using LKB ampholine with a pH range of 3 to 6 . The pili sample applied to the column was from strain $91 \mathrm{~B}$ purified by acid precipitation, $\mathbf{M g C l}_{2}$ precipitation and gel filtration on BioGel A150. The fraction volumes were $2 \mathrm{ml}$. $\bigcirc$, Absorbance at $280 \mathrm{~nm} ; \square, \mathrm{pH}$ at $4{ }^{\circ} \mathrm{C} ; 0$, pili grade.

\section{Isoelectric focusing}

Isoelectric focusing of bacteria-derived or medium-derived pili purified in a BioGel A150 column formed a single, sharply defined, opaque band in the ampholine columns at $\mathrm{pH} 4.5$ in the gradient (Fig. 2). A pI of 4.5 for pili was obtained when the isoelectric focusing was carried out in gradients of $\mathrm{pH} 3$ to $6, \mathrm{pH} 4$ to 6 , or $\mathrm{pH} 4$ to 5 . If LPS was present in the sample it was not separated from the pili by isoelectric focusing. When large samples were subjected to isoelectric focusing the pili precipitated near their isoelectric point and fractionation of the column proved difficult. Pili from $B$. nodosus strain 80 also had a pI of $4 \cdot 5$.

\section{Buoyant density in caesium chloride}

Iso-density gradient ultracentrifugation of pili resulted in a single, sharply defined, opaque band at a density of $1.287 \pm 0.003 \mathrm{mg} \mathrm{ml}^{-1}$ (mean of two experiments \pm standard deviation) for pili of strain 91B (Fig. 3), a density of $1.284 \pm 0.003 \mathrm{~g} \mathrm{ml}^{-1}$ (four experiments) for pili of strain 80 and a density of $1.286 \mathrm{~g} \mathrm{ml}^{-1}$ for pili of strain 198 . 


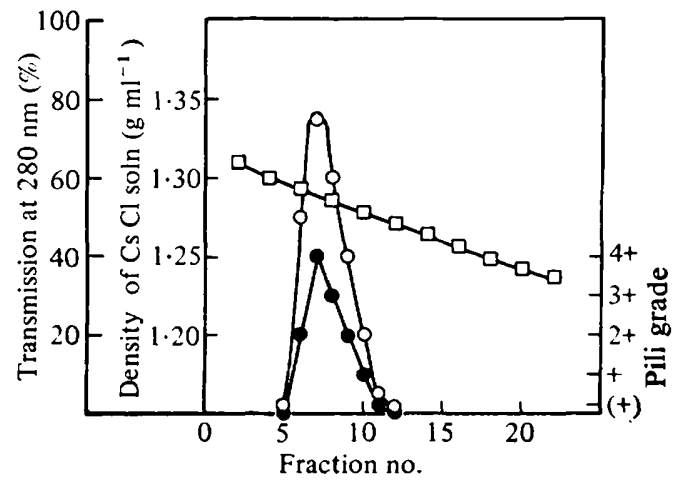

Fig. 3. Iso-density gradient ultracentrifugation of pili on $\mathrm{CsCl}$. The pili sample used was from strain $91 \mathrm{~B}$ which had previously been purified by acid precipitation, $\mathbf{M g C l}_{2}$ precipitation and gel filtration on BioGel A150. The fraction volumes were $0.35 \mathrm{ml}$. $O$, Transmission at $280 \mathrm{~nm} ; \square$, density of $\mathrm{CsCl}$ solution; $\mathrm{O}$, pili grade.
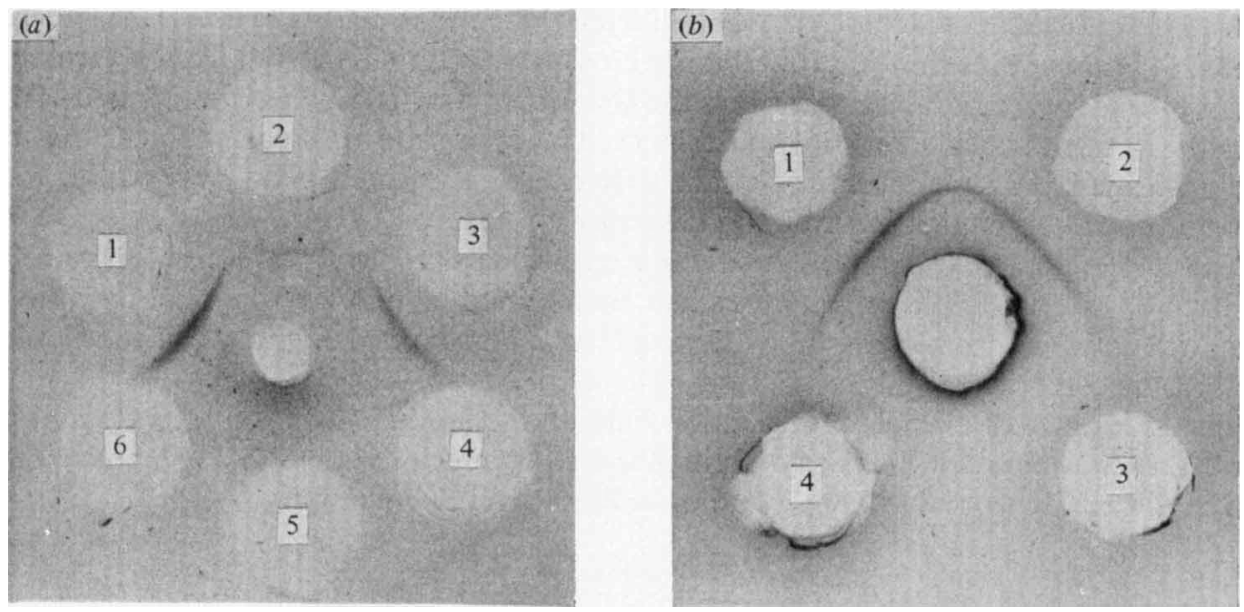

Fig. 4. Immunodiffusion patterns of anti-pili and anti-whole bacteria sera versus various pili preparations and LPS.

(a) The centre well contained $1 \mu \mathrm{l}$ of undiluted antiserum against pure medium-derived pili from strain $91 \mathrm{~B}$. Outer wells contained: (1) $30 \mu \mathrm{g}$ of pure medium-derived pili from strain $91 \mathrm{~B}$; (2) crude surface antigen from $4 \times 10^{7} \mathrm{~B}$. nodosus strain $91 \mathrm{~B}$ prepared by homogenizing the cells for $2 \mathrm{~min}$ at full speed and taking the supernatant after centrifugation at $12000 \mathrm{~g}$; (3) $30 \mu \mathrm{g}$ of pure bacteriaderived pili from strain 91B; (4) $20 \mu \mathrm{g}$ of LPS purified from strain 91B by the method of Westphal \& Jann (1965); (5) $30 \mu \mathrm{g}$ of pili purified from strain 198; (6) $30 \mu \mathrm{g}$ of pili purified from strain 80 .

(b) The centre well contained $30 \mu \mathrm{g}$ of pure bacteria-derived pili from strain $91 \mathrm{~B}$. Outer wells contained: (1) and (2) half-dilution of antiserum against whole bacteria strain 91B; (3) undiluted antiserum against whole bacteria strain 80 ; (4) undiluted antiserum against whole bacteria strain 198.

\section{SDS-polyacrylamide gel electrophoresis}

Only one sharply defined protein staining band per gel resulted when $10 \mu \mathrm{g}$ of the most highly purified pili preparations were subjected to SDS-polyacrylamide gel electrophoresis. The molecular weight of this pilin band was determined as $18400 \pm 300$ (average of 10 gels \pm standard deviation) for strain 91 B, $19300 \pm 400$ (4 gels) for strain 80 and $18400 \pm 300$ (10 gels) for strain 198. Bacteria-derived and medium-derived pilin subunits were identical in molecular weight.

SDS-polyacrylamide gel electrophoresis of gels overloaded with $60 \mu \mathrm{g}$ of purified pili from $B$. nodosus strain 91B resulted in one heavily stained band of pilin and one just detectable 
Table 1. Agglutination titres of various anti-bacterial sera and anti-pili serum with various strains of whole bacteria

\begin{tabular}{ccccc} 
& \multicolumn{4}{c}{ Antiserum against: } \\
Antigen strain & Strain 91B & Strain 80 & Strain 198 & $\begin{array}{c}\text { Purified pili, } \\
\text { strain 91B }\end{array}$ \\
$91 B$ & 10240 & $<10$ & 20 & 20480 \\
80 & $<10$ & 5120 & 20 & 10 \\
198 & 40 & $<10$ & 640 & 20
\end{tabular}

band of protein impurity. The impurity had a molecular weight of $14200 \pm 200$ (average of 7 gels \pm standard deviation), and densitometric protein quantification showed that it constituted less than $0.4 \%$ of the total protein. Similarly overloaded gels showed no detectable staining of the pilin band when stained for glycoprotein, lipid and phosphoprotein.

\section{Serology}

Medium-derived and bacteria-derived pili from the same strain (91B) of B. nodosus crossreacted in immunodiffusion gels, but did not cross-react with pili derived from heterologous strains 80 and 198 (Fig. 4). This parallels the lack of cross-reactivity between strains 91B, 80 and 198 in agglutination reactions (Table 1). The antiserum produced against the most highly purified pili preparation of strain 91B caused the characteristically rapid, loose, floccular K-type agglutination reaction described by Egerton (1973).

The K-agglutinogen was a heat-sensitive antigen which was destroyed by heating at $100^{\circ} \mathrm{C}$ for $10 \mathrm{~min}$. After pure pili preparations had been heated at $100{ }^{\circ} \mathrm{C}$ for $10 \mathrm{~min}$ they did not react with anti-pili serum in immunodiffusion tests and contained no intact pili detectable by electron microscopy.

The appearance of a single precipitation band in the immunodiffusion tests (Fig. 4) provided further evidence of the purity of pili prepared by precipitation at $\mathrm{pH} 4 \cdot 0$, precipitation with $\mathrm{MgCl}_{2}$ and chromatography twice on a BioGel A150 column.

\section{DISCUSSION}

Ottow (1975) has made provisional groups for the wide variety of non-flagellar appendages which have been recognized on many Gram-negative and a few Gram-positive bacteria. The pili of $B$. nodosus seem to fall into the category of group 4, an example of which are the pili of Pseudomonas aeruginosa which have the following properties: they are polarly arranged, flexible, rod-like filaments having a diameter of $6 \mathrm{~nm}$ and an average length of $2500 \mathrm{~nm}$; they have no axial hole; they do not act as attachment organelles but do promote bacterial motion; they are composed entirely of protein with pilin subunits of molecular weight 17800 , buoyant density on $\mathrm{CsCl}$ of $1.295 \mathrm{~g} \mathrm{ml}^{-1}$, isoelectric point of $\mathrm{pH} \mathrm{3.9}$ and u.v. absorption maximum at $280 \mathrm{~nm}$ (Frost \& Paranchych, 1977; Weiss, 1971). Bacteroides nodosus pili are very similar in that they are polarly arranged, have a diameter of 5 to $6 \mathrm{~nm}$, have no axial hole, have no adhesive properties, and are composed entirely of protein with pilin subunits of molecular weight 18400 , buoyant density on $\mathrm{CsCl}$ of $1.287 \mathrm{~g} \mathrm{ml}^{-1}$, isoelectric point of $\mathrm{pH} 4.5$ and a u.v. absorption spectrum with a maximum at $278 \mathrm{~nm}$ and an inflection at 284 to $287 \mathrm{~nm}$. The minor absorption peak at $287 \mathrm{~nm}$ in the u.v. absorption spectrum of pure pili type I from $E$. coli is attributed to tyrosine with the hydroxyl group either hydrogen-bonded to a carboxyl group or imbedded in a non-polar environment within the pilin molecule (Brinton, 1965).

A major difficulty in purifying pili in this study was the complete removal of LPS. The methods of sedimenting pili by acidification, $\mathrm{MgCl}_{2}$ precipitation, $\left(\mathrm{NH}_{4}\right)_{2} \mathrm{SO}_{4}$ fractionation, 
methanol precipitation and centrifugation all left a persistent LPS contamination. Similar difficulties were experienced in the removal of LPS or LPS-containing outer envelope material from pili prepared from Neisseria gonorrhoeae (Novotny \& Turner, 1975; Robertson et al., 1977) and Moraxella nonliquefaciens (Frøholm \& Sletten, 1977). DEAE-cellulose chromatography and isoelectric focusing of $B$. nodosus pili did not remove all the LPS. The only reliable method was gel filtration on BioGel A150. It would thus seem that pili have a close association with LPS or possibly an LPS-phospholipid-protein complex similar to that excreted into the nutrient medium by $E$. coli and Salmonella typhimurium (Rothfield \& Pearlman-Kothencz, 1969). The pili preparations used in the vaccine protection trials by Stewart $(1975 a, 1978 a)$ and the K-agglutination experiments by Walker et al. (1973) and Stewart $(1975 a, 1978 a, b)$ were only purified by repeated sedimentation by acidification, $\mathrm{MgCl}_{2}$ precipitation and differential centrifugation. The preparations would probably have been contaminated with LPS and possibly nucleic acid, as indicated by the presence of carbohydrate and the u.v. absorption spectrum which was more characteristic of nucleic acid than of protein (Stewart, 1975a). It is noteworthy that the pili purified by Stewart $(1975 a, 1978 b)$ had a polypeptide subunit molecular weight of 14500 ; this closely approximates the molecular weight of the trace impurity detected in the pili preparations reported in this paper.

In spite of this discrepancy, the results of Stewart $(1975 a, 1978 a, b)$ and Walker et al. (1973), indicating an association between pili and the K-agglutinogen of B. nodosus, have been confirmed by my results which showed that antiserum to highly purified pili gave a typical K-type agglutination with homologous $B$. nodosus strain $91 \mathrm{~B}$ but not with strains 80 or 198. Furthermore, in the electron microscope the agglutinated bacteria appeared to be held together by antibody binding to pili. The lack of cross-reaction between different strains in the K-agglutination test corresponds to the lack of cross-precipitation in the immunodiffusion test between purified pili and heterologous antisera. Investigations of the protective immunogenic properties of highly purified pili in inoculated sheep exposed to foot rot infection will be reported elsewhere.

I wish to express my gratitude to Dr T. M. Skerman for his advice and encouragement and to Mrs W. J. Lorentz, Mr W. J. O'Kane and Mrs S. K. Erasmuson for technical assistance.

\section{REFERENCES}

Abodeely, R. A., Palmer, E., Lawson, L. A. \& RANDALl, C. C. (1971). The proteins of enveloped and de-enveloped equine abortion (Herpes) virus and the separated envelope. Virology 44, 146-152.

Brinton, C. C. (1965). The structure, function, synthesis and genetic control of bacterial pili and a molecular model for DNA and RNA transport in gram-negative bacteria. Transactions of the New York Academy of Sciences 27, 10031054.

COOPER, B. S. (1977). Differences in morphology of Bacteroides nodosus attributable to culture media. New Zealand Veterinary Journal 25, 16-20.

Cutring, J. A. \& Roth, T. F. (1973). Staining of phospho-proteins on acrylamide gel electrophoresis. Analytical Biochemistry 54, 386-394.

Dubois, M., Gilles, K. A., Hamilton, J. K., Rebers, P. A. \& Smith, F. (1956). Colorimetric method for the determination of sugars and related substances. Analytical Chemistry 28, 350-356.
EGERTon, J. R. (1973). Surface and somatic antigens of Fusiformis nodosus. Journal of Comparative Pathology 83, 151-159.

EGERTON, J. R. (1974). Significance of Fusiformis nodosus serotypes in resistance of vaccinated sheep to experimental foot rot. Australian Veterinary Journal 50, 59-62.

Frøholm, L. O. \& Sletten, K. (1977). Purification and N-terminal sequence of a fimbrial protein from Moraxella nonliquefaciens. FEBS Letters 73, 29-32.

Frost, L. S. \& Paranchych, W. (1977). Composition and molecular weight of pili purified from Pseudomonas aeruginosa K. Journal of Bacteriology 131, 259-269.

JANDA, J. \& WoRK, E. (1971). A colorimetric estimation of lipopolysaccharides. FEBS Letters 16, 343-345.

Novotny, P. \& Turner, W. H. (1975). Immunological heterogeneity of pili of Neisseria gonorrhoeae. Journal of General Microbiology 89, 87-92. Oттоw, J. C. G. (1975). Ecology, physiology, and 
genetics of fimbriae and pili. Annual Review of Microbiology 29, 79-108.

OUCHTERLONY, Ö. (1958). Diffusion-in-gel methods for immunological analysis. Progress in Allergy 5, $1-78$.

Robertson, J. N., Vincent, P. \& Ward, M. E. (1977). The preparation and properties of gonococcal pili. Journal of General Microbiology 102, 169-177.

Rothfield, L. \& Pearlman-KothenCz, M. (1969). Synthesis and assembly of bacterial membrane components. A lipopolysaccharide-phospholipidprotein complex excreted by living bacteria. Journal of Molecular Biology 44, 477-492.

SEGREST, J. \& JACKSON, R. L. (1972). Molecular weight determination of glycoproteins by polyacrylamide gel electrophoresis in sodium dodecyl sulphate. Methods in Enzymology 28B, 54-63.

Shapiro, A. L., Vinuela, E. \& Maizel, J. V. (1967). Molecular weight estimation of polypeptide chains by electrophoresis in SDS-polyacrylamide gels. Biochemical and Biophysical Research Communications 28, 815-820.

Short, J. A., Thorley, C. M. \& Walker, P. D. (1976). An electron microscope study of Bacteroides nodosus: ultrastructure of organisms from primary isolates and different colony types. Journal of Applied Bacteriology 40, 311-315.

Skerman, T. M. (1975). Determination of some in vitro growth requirements of Bacteroides nodosus. Journal of General Microbiology 87, 107-119.

StewarT, D. J. (1973). An electron microscope study of Fusiformis nodosus. Research in Veterinary Science 14, 132-134.

StEWART, D. J. (1975a). Studies on the morphology and antigenetic structure of Fusiformis nodosus. Ph.D. thesis, University of Sydney, Australia.

StewarT, D. J. (1975b). Antigens of Fusiformis nodosus and their relation to immunity of sheep to foot rot. Proceedings of the 20th World Veterinary Congress, Thessaloniki 2, 1395-1398.

StewarT, D. J. $(1978 a)$. The role of various antigenic factors of Bacteroides nodosus in eliciting protection against foot rot in vaccinated sheep. Research in Veterinary Science 24, 14-19.

Stewart, D. J. $(1978 b)$. Studies on the antigenic structure of Bacteroides nodosus. Research in Veterinary Science 24, 293-299.

Thorley, C. M. (1976). A simplified method for the isolation of Bacteroides nodosus from ovine foot rot and studies on its colony morphology and serology. Journal of Applied Bacteriology 40, 301309.

Walker, P.D., Short, J., Thomson, R. O. \& ROBERTS, D.S. (1973). The fine structure of Fusiformis nodosus with special reference to the location of antigens associated with immunogenicity. Journal of General Microbiology 77, 351-361.

WARburG, O. \& Christian, W. (1941). Isolierung und Kristallisation des Gärungsferments Enolase. Biochemische Zeitschrift 310, 384-421.

WEISS, R. L. (1971). The structure and occurrence of pili (fimbriae) on Pseudomonas aeruginosa. Journal of General Microbiology 67, 135-143.

WestPhal, O. \& JANN, K. (1965). Bacterial lipopolysaccharides. Extraction with phenol-water and further applications of the procedure. Methods in Carbohydrate Chemistry 5, 83-91.

Wyckoff, M., Rodbard, D. \& Chrambach, A. (1977). Polyacrylamide gel electrophoresis in sodium dodecyl sulfate-containing buffers using multiphasic buffer systems: properties of the stock, valid $\mathbf{R}_{\mathrm{f}}$-measurement, and optimized procedure. Analytical Biochemistry 78, 459-482. 